\title{
Effect of Public Elementary School Financial Challenges on Student Achievement
}

\author{
Syahriar Ardanto Wibowo ${ }^{1, *}$, Rukayah, Mintasih Indriayu \\ Universitas Sebelas Maret, Jalan Ir. Sutami 36, Jebres, Surakarta, Jawa Tengah 57126 \\ ${ }^{1}$ syahriarardanto@gmail.com* \\ *corresponding author
}

\begin{abstract}
\begin{tabular}{l|l} 
ARTICLE INFO ABSTRACT & ART
\end{tabular}
Article history

Received January 6, 2019

Revised February 2, 2019

Accepted April 30, 2019

Keywords

Elementary school

Financing

Student Achievement

The quality of education is often seen from the achievements of students. Meanwhile, student achievement in school is influenced by many factors. The financing factor is one factor that cannot be separated from the teaching and learning process. The relationship between educational funding and student achievement is still being debated. This study aims to reveal the relationship between the number of funding resources in schools and student achievement. This research used qualitative methods. Data collection was carried out using interviews, observation, and documentation techniques. The collected data were analyzed using interactive model analysis and purposive sampling techniques. The results of this study indicate that public elementary schools have limited sources of funding. The amount of money managed by one school differs depending on the number of students and the ability of parents. This study finds that education funding has no direct effect on student achievement. Schools that have significant financial resources do not necessarily have high achievements. The effectiveness of schools in managing their finances also becomes essential. Besides, the role of policymakers, the ability of teachers, and the participation of parents are crucial to increase the education quality.

Kualitas pendidikan banyak dilihat dari prestasi siswanya, prestasi siswa di sekolah dipengaruhi oleh banyak faktor. Faktor pembiayaan menjadi salah satu faktor yang tidak bisa dilepaskan dari proses belajar mengajar. Hubungan antara pembiayaan pendidikan dengan prestasi siswa masih menjadi perdebatan. Tujuan dari penelitian ini adalah untuk mengungkap hubungan antara jumlah sumber daya pembiayaan di sekolah dengan prestasi siswa. Penelitian ini merupakan sebuah studi kasus menggunakan metode kualitatif. Pengumpulan data dilakukan menggunakan teknik wawancara, observasi, dan dokumentasi. Data yang sudah terkumpul dianalisis menggunakan analisis model interaktif dan menggunakan teknik purposive sampling. Hasil dari penelitian ini menunjukkan bahwa Sekolah Dasar Negeri memiliki sumber pembiayaan yang terbatas. Besarnya uang yang dikelola sekolah satu dengan sekolah lain berbeda bergantung pada jumlah siswa dan kemampuan orang tua siswa. Kami menemukan bahwa pembiayaan pendidikan tidak berpengaruh secara langsung terhadap prestasi siswa. Sekolah yang memiliki sumber daya pembiayaan yang besar belum tentu memiliki prestasi yang tinggi pula. Keefektifan sekolah dalam mengelola keuangannya menjadi hal yang penting. Selain itu, peran pengambil kebijakan, kemampuan guru, dan peran serta orang tua merupakan hal yang sangat penting dalam memajukan pendidikan siswa.
\end{abstract}

This is an open access article under the CC-BY license.

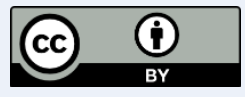

\section{Introduction}

Every country has the goal of having a good quality of education. Quality of Education can be seen from the results achieved by students. The problem that is still being debated is the relationship between student achievement and the cost of education incurred by the school. Previous research shows 
that changes in school funding have little effect on student test scores (Neymotin, 2010). However, (Tran, 2017) said that one way to improve students' academic achievement could also be supported by salaries given to teachers. In addition, research on the impact of education funding on student achievement has been carried out with a quantitative approach in the form of quasi-experiments (Card \& Payne, 2002; Jackson et al., 2016; Tandberg \& Hillman, 2014). This study used a qualitative approach to capture the direct meaning of the research subject.

Government policies in financing education are also a determining factor in the progress of education. Education Funding is one of the resources needed to run school operations. The use of educational resources results in the costs required. The cost of education is used to finance various things, including educators and education staff, as well as educational facilities.

The government of Indonesia has a policy related to educational financing through the School Operational Assistance (BOS) program. School Operational Assistance is a program of the Indonesian government to provide funding for personnel and non-personnel operating costs for Schools sourced from nonphysical special allocation funds (Menteri Pendidikan dan Kebudayaan Indonesia 2019). The government offers BOS intending to reduce the cost of education for students while still improve the quality of school education. BOS provides funding for non-personnel operating costs for basic education units as education providers. BOS can be used to fund activities organized by the school, such as the purchase of books, extracurricular activities, and maintenance of school facilities and infrastructure. The usage of BOS is still regulated based on existing technical instructions. Public schools are not allowed to charge students. Therefore, schools must be smart in managing their current finances. No matter where the source of education funding is and how to use the funds, it must be focused on learning services that affect educational quality.

Schools, as an education provider, need to develop their ability to analyze the costs needed for school operations that have a significant correlation with the quality of education that they will obtain (Sagala, 2009). Public schools in Indonesia with limited financial resources must manage finances appropriately because schools will have difficulty if they only use School Operational Assistance funds. Thus, this research investigated the issue of how public schools in Indonesia find sources of funds and allocate them to improve the quality of education in schools that was seen from the results of students' National Exams.

Education funding in Indonesia has the primary goal of equitable distribution and access to education services expansion. The fact that students with limited resources have lower grades than students who have sufficient supporting resources. This is caused by differences in socioeconomic aspects (Clotfelter et al., 2006; Fryer, R \& Levitt, S, 2004). That also happens in Indonesia; therefore, support from the government in education is essential. The commitment of the Indonesian government in improving access and quality of education is realized by launching the School Operational Assistance (BOS) program, which began in 2005. In 2005, BOS was only intended for needy students. Then, it was developed to provide the school funding in accordance with the number of students in that school. BOS is a government subsidy program with the largest allocation of national funding. This funding is intended to finance school operations, registration of new students, books, and class stationery, as well as conducting assessments and developing teacher competencies.

School Operational Assistance (BOS) is an education subsidy program that is designed to reduce the operational costs of schools both in public schools and private schools. Subsidies are given with the assumption that they will increase the level of school sustainability, reduce dropout rates, and improve student achievement. The existence of BOS has affected the students. It has a positive influence on dropout rates in Indonesia (Kharisma, 2013). Although BOS did not have a significant effect on dropout rates, BOS has eased education costs, especially for needy families.

School Operational Assistance (BOS) is channelled directly from the government to the accounts belonging to each school. The educational level differentiates the amount of funding. In 2019, elementary school level got IDR 800,000.00 funding from the BOS program; junior high school level got Rp. $1,000,000.00$; then, high school level got Rp. $1,400,000.00$; vocational high school got Rp. $1,600,000.00$, and the special needs / extraor- 
dinary education levels got Rp. 2,000,000.00. The amount is given based on the needs of each educational unit and multiplied by the number of students, if every education unit has the same needs with the same component activities. The BOS funds are determined based on the number of students in education services. That is done to assure justice because each school receives a budget by the target number of recipients of education services (Rusmana \& Hamdani, 2015). However, the determination of BOS does not consider the complexity of each school, as well as the different school program activities conducted to increase the creativity and maintain the amount of BOS given by the government.

The granting of School Operational Assistance (BOS) funds based on the number of students in each Elementary School cannot be used arbitrarily. The BOS grant must be used based on the annually updated Minister of Education Regulation, which becomes the technical guide to implement BOS. Most of the funding sources for education in public elementary schools come from BOS funds. However, based on Minister of Education and Culture Regulation No. 44 of 2012 concerning Fees and Contribution of Education Costs to the Elementary Educational Unit, Local Governments' elementary schools are not allowed to collect fees but are still permitted to receive donations or assistance from students and institutions concerned, as long as not in the form of forcing (Kemendikbud, 2019). Based on this regulation, the school can utilize the potential sources of funding for education from the community and neighbor environment around the school to support its education processes.

Schools have challenges in managing funding to improve the quality of their education. Decision making related to learning processes will be more effective if it is done by schools compared to central government institutions (Al-Samarrai, 2015). The school is in the most suitable position to determine its funding. Schools themselves understand what are needed in organizing education processes. The school has the authority to regulate all its resources. School resource theory mentioned that if a school is given more resources, it improves the performance of its students. The resources are included but not limited to money resources and everything that can be bought with it.
The school has the authority to manage itself through the school-Based Management (SBM) program. School-Based Management $(\mathrm{SBM})$ is a form of decentralization of authority from the central government to the school level (Caldwell, B, 2005). Schools are given full responsibility to manage all the resources they have. The authority given to schools includes budget allocation, management of educators and education personnel, curriculum development, books and learning needs, school infrastructure development, school calendars, and monitoring and evaluation of teachers and student achievement. In line with this scheme, this can increase parents, students, teachers, and principals, as well as the neighbour community around the school, communication to participate in developing a school capacity. Therefore, a forum that creates effective communication between the stakeholders is needed (Pardji, 2011).

The main objectives of the School-Based Management (SBM) program are: (1) increasing student's parent and community participation in schools; (2) strengthening the capacity of school principals and teachers; (3) enhancing transparency in the process of delegating authority and reporting; (4) increasing the efficiency, effectiveness, and quality of schools that affect student achievement (Gertler et al., 2012). The school has the authority and responsibility to manage their monetary fund of each school. Schools will analyzed their needs, carry out planning, determine the source of funds, carry out activities, and even report their financial condition to the government.

Implementation of Education in schools is a business expected to bring benefits, not only for individuals who take part in Education but also for peers and the wider community who use school services. The community and government demand highly qualified schools.. Highly qualified schools can be seen from the achievements they get in the academic and non-academic fields. Educational achievement on a broader scale can be seen through the results of student examinations (Card \& Payne, 2002). Student test scores can also describe their learning habits at home and the role of parents in supporting their children to learn. This study analysed the national exam because of the national exam to measure the distribution of the quality of education in Indonesia. National exam results are used as predictors or factors that affect school quality (Raharjo et al., 2018). National exams were 
used to gain information about mastery learning achievement in school. Student test scores were considered as a natural benchmark to see student learning outcomes. From a financial perspective, school planning to prepare students for national exams can also be used as a consideration. The community as users of school services will also look at the quality of schools by considering the results of examinations obtained by schools.

\section{Method}

This study used qualitative research methods because the researcher wanted to find out the detail of how schools manage their funding, as well as the effect on the school quality. Qualitative research is a research process based on investigating phenomena used to build understanding by the researcher (Creswel, 2008; Harsono, 2011). Educational funding is a complex activity, so the researcher needed to collect data, understand each activity, and the observable events. After that, the researcher described and explained the process of managing education funding in elementary schools and their impact on the quality of education in elementary schools.

This research was conducted in two elementary schools in Boyolali District, Boyolali Regency, and Central Java, Indonesia. The school was chosen to be the object of research using a purposive sampling technique. Purposive sampling is a way to determine the sample with specific considerations to achieve research objectives (Sugiyono, 2013). The schools were chosen because they considered having almost the same characteristics, seen from the number of students and the availability of existing facilities and infrastructure.

The primary data collection instrument in qualitative research is the researcher himself. However, in this study, several data collection techniques were employed: (1) direct observation aimed to observe the process of managing to fund in elementary schools; (2) in-depth interviews; (3) document analysis carried out by collecting and analysing written documents, images and electronic. The schools have some steps to manage their funding, from planning, implementation, and reporting the funding condition with the aim is to improve the quality of education. Besides, the interviews were conducted in two ways, namely structured interviews, by preparing a list of questions and un- structured interviews that take place flexibly to gather information. The interviews were conducted with school principals, committees, and teachers who served as school treasurers. These people played a direct role in managing funds as well as implementing all activities in schools. The interview was recorded with a voice recorder; then, the results were transcribed. Field notes were also taken during the interviews to support the result. The transcripts and field notes were used to analyse the meaning obtained during the interview. The researcher analyzed several data, the annual School Budget Work Plan, photo/video observations of budget use, and student achievement books that record student activities during competitions. The document can also be used to prove the results of the interviews.

The data that has been collected must be validated for the accuracy of the research results. The validation process considered the aspects of credibility, transferability, dependability, and confirms ability. Triangulation was used as a way to test the validity of data by checking and comparing it with something else (Moleong, 2014). The triangulation method was used to check research results and compared the interviews, observations, and document analysis results. The data analysis technique used in this study was an interactive model analysis that used; (1) data reduction on school financial governance and its impact on student achievement; (2) data presentation in the form of a narrative description of the data that has been reduced; (3) drawing conclusions.

\section{Results and Discussion}

BOS aids aiming to erase the cost of education for students who cannot afford and ease the burden for other students from elementary to high school level. The distribution of BOS funds is carried out every three months/quarterly, namely the period JanuaryMarch, April-June, July-September, and October-December. The amount of BOS funds for each school is based on the number of students in the school. Student data is taken by doing a cut-off from the Basic Education Data. That data contains individual student data that is validly inputted by the school once they registered to the school.

BOS funds are received directly into school accounts without deductions from any party. The use of Regular BOS funds is only 
for improving education services. It is managed independently by the school by involving the teacher board and school committee based on SBM policy. The school manages its finances from the planning process, implementation, to reporting the usage of funding. Financing activities are carried out following applicable regulations. The results of interviews shows that schools were required to prepare a Medium-Term Work Plan (Rencana Kerja Jangka Menengah/RKJM) prepared once in 4 years, compile an Annual Work Plan (Rencana Kerja Tahunan/RKT) then from the RKT to be used as a guideline for preparing School Activity and Budget Plans (RKAS).

The Medium-Term Work Plan (RKJM) contains the general condition of schools, strategic analysis of school development, school vision and mission, and school programs plan. Then the RKJM consists of funding allocation for each program integrated with the RKAS. The School Activity and Budget Plan (RKAS) contain the program planned by the school along with details of the costs needed during one fiscal year. RKAS subsists sources of funds obtained by schools both from School Operational Assistance (BOS) and from other sources. Funding included in the RKAS is only expenditures in the form of money to be received and managed by the school. From the two schools, the preparation of the RKAS was carried out in several stages. An interview with the Principal of SDN Susiloharjo stated that "in our planning, there is a Pre-plenary meeting between the committee and the school committee to determine the activity and financing plan and then make a decision at the plenary meeting."

The first stage of making RKAS is the Pre-Plenary meeting. At this stage, the school consists of the principal, the teacher board, and representatives from the School Committee compile a program plan for the next year and evaluate the program realization from the previous year. This school self-evaluation is shown from the school's Quality Report. The quality report card is a program from the ministry to facilitate the mapping of school quality. School progress is measured by comparing to the indicators on eight National Education Standards.

The Indonesian government mandates eight national education standards; they are standards of graduates' competency, content, process, teachers and teaching staff, facilities and infrastructure, management, financing, assessment. These standards are used as an essential measure to implement an education which affects financial planning (Government of Indonesia 2013)

Interview result with the Principal of Elementary School (SDN) 9 Boyolali: "The school quality report contains all the activities in this school that describe eight National Education Standards along with all the indicators. For example, for Educators, stated that for being a class teacher, they must be a bachelor specifically on Elementary School Teacher Study Program. Then this indicator is adjusted to the real situation at school. All components in the school are included in the quality report cards ranging from students, committees, teachers, and principals its selves, everything should be included in the report. The result shown in this report is how big is the situation in schools compared to the indicators in the Quality Report."

School Quality Reports accessed by schools online based on data reported by schools about the state of the school for a one-year program. The analysis is carried out to determine the weaknesses and strengths of schools. The analysis also shows which programs have been successfully implemented and which have not been successful or need more improvement in the implementation. Programs that have not yet succeeded are a priority in the next fiscal year planning. The team also plans another program other than the annual programs, such as midterm and final tests. The other program is designed based on the results of the school development strategy analysis.

The Principal of SDN Susiloharjo stated: "The school made an evaluation of the school were based on the obtained strengths and weaknesses. Then the priority scale of financing is to improve the weakness factor in the next year. The evaluation results show if there is an increase in the quality report or not. From that result, the school prepares a priority scale in accordance with underlying regulation. We will use the data to prioritize the weak program to be funded."

After determining the scale of priorities, the financing team determines the required allocations for each program. The allocation of each school program includes not only the required expenses but also plans from which sources of income will be used to pay. The 
source can come from BOS funds or from parents' donations. In this stage, the School Committee takes part in determining the amount to be given to each program. The committee, as a representative of the students' guardians, provides support while overseeing the activities in the school. The school communicates with the committee about what they will need for next year. All plans contained in the RKT and RKAS are submitted to the Committee.

Chairperson of SDN 9 Boyolali Committee revealed: "Every time the school makes a policy, especially about financing, the Committee must be informed. The principal always communicates with us about all the necessary needs. Starting from the need for infrastructure, including if there are plans for school development, for example, chair table procurement to maintain the broken one, procurement for a drum band with the aim of leverage the school quality by providing many extracurricular for the student. So, all school needs are always synergized with the Committee. That is why the Committee must be included from the planning stage."

The pre-plenary program regulates what programs should be carried out even though it is still in a small committee between the school and the committee as parents' representatives. The preparation of the RKAS also based on the school's vision and mission and school needs for the next fiscal year, besides its self-evaluation. The principal of SDN 9 Boyolali emphasized that "the priority scale of financial planning is seen from the needs of schools to be considered in making decisions which program that will be budgeted first."

School needs are a consideration that must be seen when planning RKAS. The needs of one school to another school are different, making each school have different priorities, especially in the provision of facilities and infrastructure. For example, schools must make a priority scale between the procurement of laptops and the procurement of desk chairs. This is very important because the amount of funds managed by schools is very limited.

The draft of RKAS prepared during the Pre-Plenary Meeting is then discussed again during the Plenary Meeting. The Plenary Meeting involves all parties in the school, from the principal, the teacher board, the Committee, and all parents from grade 1 to grade 6 . The RKAS is reviewed jointly by all plenary participants. The school conveys all programs to be implemented, and the number of funds is needed. Then all plenary participants responded to the school program planning. Student guardians are given the opportunity to provide support and advice on programs planned by the school then the student guardian and the Committee decide on the amount of the contribution given to the school based on the school's proposed cost.

The principal of SDN 9 Boyolali replied: "The amount of the contribution is deliberated between the Committee and the parents themselves. That means that the school does not interfere with the decision-making process. School provides opportunities for student guardians to discuss with each other without any intervention from the school. The school only proposed its needs; for example, I need to pay teachers' honorary, then I also need to prepare for the National Examination. So, the decision is handed back to the guardians of students because the school cannot afford it if we have to pay for everything by ourselves."

The RKAS that has been reviewed and improved in accordance with the agreement was approved by all plenary participants. The agreed RKAS is expected to run into an effective and efficient program. Based on the results of interviews and observations, all funds from students' guardians are managed solely by student guardians who establish class associations to manage the funds. The class associations are an extension of the school committee and guardians of students in each class. They oversee making the class needs meeting to programs held by the school. The interview results illustrate that parental awareness can be a supporting factor as well as an obstacle in education funding. Both principals agreed that the parents' high awareness would be very supportive of educational activities. The level of education of parents is also very crucial. Parents who have a high educational background tend to have higher awareness so that the carrying capacity of the school is even higher.

Table 1 shows the RKAS at SDN Susiloharjo in the 2018 budget year for national exam preparation. The RKAS has been implemented by schools for several years. This budgeting is used for doubling the question sheet for national exam try out activities. SDN Susiloharjo planned to conduct six times national exam try out in 2018. Table 1 shows 
that the committee hasn't participated in this activity, shown that they put all costs to the School Operational Assistance (BOS) fund.
Schools only budget for trials at the subdistrict and district levels.

Table 1. Expenses on national Exam preparation of SDN Susiloharjo in 2018

\begin{tabular}{lccccc}
\hline Activity & Number of students & Cost/unit & Total cost & \multicolumn{2}{c}{ Funding resource (Rp) } \\
\cline { 5 - 6 } & & $(\mathbf{R p )}$ & $(\mathbf{R p )}$ & BOS & Student Committee \\
\hline Try Out 1 & 32 & $15.000,00$ & $480.000,00$ & $480.000,00$ & - \\
Try Out 2 & 32 & $15.000,00$ & $480.000,00$ & $480.000,00$ & - \\
Try Out 3 & 32 & $15.000,00$ & $480.000,00$ & $480.000,00$ & - \\
Try Out 4 & 32 & $15.000,00$ & $480.000,00$ & $480.000,00$ & - \\
Try Out 5 & 32 & $15.000,00$ & $480.000,00$ & $480.000,00$ & - \\
Try Out 6 & 32 & $15.000,00$ & $480.000,00$ & $480.000,00$ & - \\
\hline
\end{tabular}

Table 2 shows RKAS SDN 9 Boyolali in preparing tryouts for the national exam. The tryouts were carried out ten times, with five tryouts conducted independently by the school, four tryouts from the sub-district level, and one tryout from the district level. SDN 9 Boyolali conducted an independent try out. Table 2 shows the independent try out con ducted by the school with the cost gathered from the school committee and the School Operational Assistance (BOS) fund indicates that the school committee participated in preparation for the school exam. Then the trials at the sub-district and district levels were fully funded with School Operational Assistance (BOS) funds.

Table 2. Expenditures for National Examination Preparation of SD N 9 Boyolali in 2018

\begin{tabular}{cccccc}
\hline Activity & Number & Cost/unit & Total cost & \multicolumn{2}{c}{ Funding resource (Rp) } \\
\cline { 5 - 6 } of students & $(\mathbf{R p )}$ & $(\mathbf{R p )}$ & BOS & Student Committee \\
\hline Try Out 1 & 33 & $15.000,00$ & $495.000,00$ & $35.000,00$ & $460.000,00$ \\
Try Out 2 & 33 & $15.000,00$ & $495.000,00$ & $35.000,00$ & $460.000,00$ \\
Try Out 3 & 33 & $15.000,00$ & $495.000,00$ & $35.000,00$ & $460.000,00$ \\
Try Out 4 & 33 & $15.000,00$ & $495.000,00$ & $35.000,00$ & $460.000,00$ \\
Try Out 5 & 33 & $15.000,00$ & $495.000,00$ & $35.000,00$ & $460.000,00$ \\
Try Out 6 & 33 & $15.000,00$ & $495.000,00$ & $495.000,00$ & - \\
Try Out 7 & 33 & $15.000,00$ & $495.000,00$ & $495.000,00$ & - \\
Try Out 8 & 33 & $15.000,00$ & $495.000,00$ & $495.000,00$ & - \\
Try Out 9 & 33 & $15.000,00$ & $495.000,00$ & $495.000,00$ & - \\
Try Out 10 & 33 & $15.000,00$ & $495.000,00$ & $495.000,00$ & - \\
\hline
\end{tabular}

The RKAS has been formulated by schools by dividing tasks into teachers in the school. Especially for the provision of the annual needs, schools assign teachers or administrative officers to make all purchases. The interviews with the principal and teacher reveal that, the purchase of goods is completed directly to the store. Schools only manage and implement programs whose funding comes from School Operational Assistance (BOS). In contrast, funds originating from student guardians are managed by the class association together with the Committee. The implementation of learning activities cannot be separated from financing activities.

The principal of SDN 9 Boyolali emphasized "the implementation of education relies on routine, planned, programmed, and continuous development that will produce a better output. For schools that have the funds to carry out this activity, they will certainly leverage the school level as well as school quality".

The results of interviews, observations, and document analysis indicate that the implementation of the budget use has been carried in accordance with the initial planning. The budget was used to meet the needs of the eight education standards planned in the RKAS. The management and implementation of education funding in each elementary school used its budgets to support learning activities for one year based on the applicable regulations and technical guidelines.

Regular BOS funds are prioritized for nonpersonnel school activities. BOS funds are mostly used to hold a textbook for students, which is a maximum of $20 \%$. Textbook purchases must also be adjusted to the needs of the school. Then it is used for the activities, 
such as the admission of new students, extracurricular activities, payment of honorarium for educators, as well as on learning evaluation activities.

At the end of the school budget year, schools are obliged to report all uses and School Operational Assistance (BOS) in the form of an Accountability Report to the government. Then the accountability report on the use of funds from student guardians is reported to the student guardians and the Committee.

The whole series of activities that have been planned and funded by schools have the goal of improving the quality of education in schools. Schools, as providers of educational services, are responsible for meeting the expectations of the community as service users as well as being responsible to the government to carry out a good quality of education. Schools always try to organize education effectively and efficiently.

The principal of SDN 9 Boyolali response to the implementation of effective and efficient education was: "If the quality of graduates is the same as the expectations of the community, it because their parents already have their plans when choosing schools for their children."

Parents of students will prefer to send their children to a decent quality school that has a high standard of education. The principal of SDN 9 Boyolali added, "The quality of education has a relation to its graduate student". Therefore, every school has a goal of im-proving the quality of school every year.

Tryouts of the national exam were conducted to prepare students for the national examination. Table 3 shows the average results of national examinations obtained by both schools in 2017 and 2018. National examination results for both schools in 2017 and 2018 showed a decrease in all subjects. However, the average national examination results obtained by SDN 9 Boyolali that have higher grades compared to SDN Susiloharjo. SDN 9 Boyolali has budgeted and conducted more national exam tryouts than SDN Susiloharjo. The Principal of SDN Susiloharjo added, "This school is still relying a lot on BOS; then, there is already a contribution from the guardians of students with the small amount".
Table 3. Result of National Exam in SDN 9 Boyolali and SDN Susiloharjo

\begin{tabular}{ccccc}
\hline & \multicolumn{2}{c}{ SDN 9 Boyolali } & \multicolumn{2}{c}{ SD N Susiloharjo } \\
\cline { 2 - 5 } & $\mathbf{2 0 1 7}$ & $\mathbf{2 0 1 8}$ & $\mathbf{2 0 1 7}$ & $\mathbf{2 0 1 8}$ \\
\hline Indonesian & 91.37 & 83.93 & 82.43 & 74.40 \\
Math & 95.43 & 85.81 & 77.36 & 67.26 \\
Science & 93.64 & 91.33 & 83.99 & 76.44 \\
\hline
\end{tabular}

This proved that all school activities could not be separated from funding. National examination results cannot describe the entire learning process in schools. However, the results of the national examination are considered as a tool to measure student output. Then it is also considered if students to continue to a higher school level.

The results of this study reveal the role of education funding on student learning outcomes in schools. The implementation of education in elementary schools is to provide the necessary abilities to their students. The delivery of education in schools cannot be separated from management activities. School-Based Management system gives authority to the school to manage its own resources. Existing financial resources in schools were obtained from School Operational Assistance (BOS) funds and student's guardian donation. The purpose of SchoolBased Management will be realized if there is good cooperation between the school and parents of students, especially in direct financing to support the development of the school. The implementation of education in schools will run smoothly with the cooperation between the school and parents. Elementary schools have more results with good collaboration between the school, the Committee, and parents (Al-Samarrai, 2015).

Schools manage their finances as a form of authority and responsibility of schools in the school-Based Management (SBM) program. This decentralization makes schools capable of taking strategic policies related to objectives, curriculum, standards, and accountability (Caldwell, B, 2005). Schools make their policies relating to operations in their respective schools. The impact of School-Based Management (SBM) has been proven to improve access to education and student learning outcomes (Bruns et al., 2011). From the planning process, schools must be able to make a priority scale by considering school needs and the funds needed. The availability and allocation of funding sources well not be effective without the abil- 
ity and purpose to help students (Neymotin, 2010). School funding sources come from the government and are very limited. Means that schools need to find other sources of funding. School Operational Assistance Funds (BOS) must be used according to specified standards. However, the standards set by the government cannot cover all school needs. Therefore, the Principal must be able to communicate with the Committee and parents to explain the conditions and needs of the school so that they got support from the Committee and student's guardian to implement all activities needed by the student.

Principals with excellent leadership skills may influence school climate, school culture, teaching and learning activities, accountability, as well as its relationships between school, family, and community (Coelli \& Green, 2012; Hallinger, 2010). The principal, as a school manager, determines the performance of the school. Exploring sources of funds to support school activities needs to be done by the school principal, such as building a good relationship with the school committee and the community around the school will increase their participation in education in the school. Parents' awareness of education also influences funding in schools. It has a positive impact on teaching and learning activities and student achievement when the school, student's family, and the community have established a good collaboration to support the school (Addonizio, M, 2009; Bryan \& Henry, 2012; Houtenville \& Conway, 2008). Parents who have an active role in school administration of education will have an impact on school quality. School programs that attract parental participation contribute to building a conducive school climate between schools and parents (Sumarsono, 2018). The educational background of parents also influences the level of parent participation in teaching and learning activities in schools. Therefore, the amount of donations is different depending on the ability of the students' parents. Priority scale determines the implementation of an effective and efficient education in schools. Good implementation in the aspects of leadership, administration, planning, and financing, along with transparency, accountability and developing active participation of parents and the community, provides the foundation needed to realize more meaningful teaching and learning activities (Heyward et al., 2011). Adequate funding will support activities in elementary schools both learning and extracurricular activities, as well as all contests that schools participate in. Then also oversee schools in reporting the realization of the use of funds that have been made by schools to create transparency and accountability of schools to the community as users of educational services.

\section{Conclusions}

This article aims to investigate the financing in public elementary schools and the effects of their management on student achievement. Limited sources of funding from the government provide opportunities for parents and the community to participate in the administration of education actively. From the result of planning, implementation, reporting of financing in elementary schools, and the national exam result achieved, we conclude that schools with higher funding sources have greater opportunities in developing activities in their schools. However, this does not mean that schools with significant financial resources guaranteed to have students with excellent achievements. Proper funding management to the needs of students and schools is an essential factor that could produce policies capable of developing student achievement. Future research should promote a similar study quantitatively. Thus, the findings can be used as a reference for schools to take opportunities to develop student achievement without relying on funding.

\section{References}

Addonizio, M, F. (2009). X-efficiency and effective schools: A new look at old theories. Journal of Education Finance, 35(1), 1-25. https://doi.org/10.1353/jef.0.0001

Al-Samarrai, S. (2015). Assing the role of the school operational grant program (BOS) in improving education outcomes in indonesia. World Bank Group.

Bruns, B., Filmer, D., \& Patrinos, H. A. (2011). Making schools work through accountability reforms. In Making schools work. https://doi.org/10.1596/9780821386798ch05

Bryan, J., \& Henry, L. (2012). A model for building school-family-community partnerships: Principles and process. Journal of Counseling and Development, 90(4), 408-420. https://doi.org/10.1002/j.1556-6676.2012.00052.x

Caldwell, B, J. (2005). School-based management. UNESCO. 
Card, D., \& Payne, A. A. (2002). School finance reform, the distribution of school spending, and the distribution of student test scores. Journal of Public Economics, 83(1), 49-82. https://doi.org/10.1016/S0047-2727(00)00177-8

Clotfelter, C. T., Ladd, H. F., \& Vigdor, J. L. (2006). The academic achievement gap in grades 3 to 8. The Review of Economics and Statistics, 91(May), 398-419.

Coelli, M., \& Green, D. A. (2012). Leadership effects: School principals and student outcomes. Economics of Education Review, 31(1), 92-109. https://doi.org/10.1016/j.econedurev.2011.09.001

Creswel, J. W. (2008). Research design: Qualitative, quantitative, and mixed methods approaches. SAGE Publications, Inc.

Fryer, R, G., \& Levitt, S, D. (2004). Understanding the black-white test score gap in the first two years of school. Review of Economics and Statistics, 86(2), 447464. https://doi.org/10.1162/003465304323031049

Gertler, P. J., Patrinos, H. A., \& Rubio-Codina, M. (2012). Empowering parents to improve education: Evidence from rural Mexico. Journal of Development Economics, 99(1), 68-79. https://doi.org/10.1016/j.jdeveco.2011.09.004

Hallinger*, P. (2010). Meeting the challenges of cultural leadership: the changing role of principals in Thailand. Discourse: Studies in the Cultural Politics of Education, 6173.

Harsono, S. (2011). Etnografi Pendidikan sebagai desain penelitian kualitatif. Universitas Muhammadiyah Surakarta.

Heyward, M. O., Cannon, R. A., \& Sarjono, S. (2011). Implementing school-based management in Indonesia: Impact and lessons learned. Journal of Development Effectiveness, 3(3), 371-388. https://doi.org/10.$1080 / 19439342.2011 .568122$

Houtenville, A. J., \& Conway, K. S. (2008). Parental effort, school resources, and student achievement. Journal of Human Resources, 43(2), 437-453. https://doi.org/10.1353/jhr.2008.0027

Jackson, C. K., Johnson, R. C., \& Persico, C. (2016). The effects of school spending on educational and economic outcomes: Evidence from school finance reforms. Quarterly Journal of Economics, 133(1), 157-218. https://doi.org/10.1093/qje/qjv036.Advance
Kemendikbud. (2019). Peraturan menteri pendidikan dan kebudayaan republik indonesia nomor 3 tahun 2019 tentang petunjuk teknis bantuan operasional sekolah reguler. In www.kemendikbud.go.id.

Kharisma, B. (2013). Dampak program bantuan operasional sekolah (BOS) terhadap tingkat putus sekolah di indonesia: Analisis did the impact of the school operational assistance (BOS) program on the dropout rate in indonesia: A did analysis. Jurnal Ekonomi Kuantitatif Terapan, 6, 7-15.

Moleong, L. J. (2014). Metodologi penelitian kualitatif. PT. Remaja Rosdakarya.

Neymotin, F. (2010). The relationship between school funding and student achievement in kansas public schools. Journal of Education Finance, 36(1), 88-108. https://doi.org/10.1353/jef.0.0026

Pardji, P. (2011). Pemaknaan penyelenggaraan pendidikan dan komite sekolah. Jurnal Ilmu Pendidikan, 17(85), 469-475.

Raharjo, S. B., Yuliana, L., \& Yudha, Y. H. (2018). Capaian standar nasional pendidikan sebagai prediktor mutu sekolah. Jurnal Pendidikan Dan Kebudayaan, 129-140.

Rusmana, M., \& Hamdani, A. (2015). Understanding the black-white test score gap in the first two years of school penentuan anggaran bos berdasarkan jumlah siswa terhadap pelayanan pembelajaran yang berkeadilan di sekolah dasar. Jurnal Ilmu Pendidikan, 21(02), 110

Sagala, S. (2009). Manajemen pembiayaan dalam organisasi pendidikan. Alfabeta.

Sugiyono, S. (2013). Metode penelitian pendidikan pendekatan kuantitatif, kualitatif, dan $R \& D$. Alfabeta.

Sumarsono, R. B. (2018). Upaya mewujudkan mutu pendidikan melalui partisipasi orang tua siswa. Jurnal Ilmu Pendidikan, 24(2), 63-74.

Tandberg, D. A., \& Hillman, N. W. (2014). State higher education performance funding: Data, outcomes, and policy implications. 39(3), 222-243.

Tran, H. (2017). does the pay stance of south carolina public school districts influence their math and science achievement scores? Journal of Education Ffnance, 43(22), 105-12205. 